RESEARCH ARTICLE



Sokoto Journal of Veterinary Sciences

(P-ISSN 1595-093X/ E-ISSN 2315-6201)

Ameji et al. /Sokoto Journal of Veterinary Sciences (2016) 14(3): 47 - 53.

http://dx.doi.org/10.4314/sokjvs.v14i3.7

\title{
Survey for Newcastle disease viruses in poultry and wild birds in Kogi state, Nigeria
}

\author{
ON Ameji ${ }^{1}$, L Sa'idu $^{2} \&$ PA Abdu ${ }^{1}$ \\ 1. Department of Veterinary Medicine, Ahmadu Bello University, Zaria-Nigeria \\ 2. Veterinary Teaching Hospital, Ahmadu Bello University, Zaria-Nigeria
}

*Correspondence: Tel.: +2348035907570; E-mail: amejivet@yahoo.com

\begin{abstract}
Newcastle disease (ND) outbreak even in the face of vaccination is a common problem in Nigeria. A survey was carried out between June, 2012 to February, 2013 to detect ND viruses in poultry and wild birds in 12 Local Government Areas (LGAs) of Kogi state, Nigeria. Oropharyngeal swabs from 710 poultry and cloacal swabs from 100 species in eight families of wild birds were tested using reverse transcription polymerase chain reaction with set of primers targeting the ND virus matrix protein with $60.5 \%$ swabs being positive. The prevalence of ND viruses was highest in live bird market with $62.5 \%$ and lowest in backyard farm with $57.7 \%$, while based on species of birds, Swallow (Hirundo spp.) had the highest prevalence with $83.3 \%$ and zero in Laughing dove (Streptopelia senegalensis). The $\chi^{2}$ value of the prevalence of ND viruses in contiguous areas A against contiguous areas $B$ was significant $\left(\chi^{2}=6.59, p \leq 0.01, O R=4.10\right.$ at $\left.95 \% \mathrm{Cl}=1.34-12.28\right)$. The study revealed the circulation of ND viruses in poultry and wild birds in Kogi state. This is the first report of ND viruses in Hirundo spp and Swift (Apus spp) in Kogi state, Nigeria. There is need for sequencing of the F-protein of the ND viruses circulating in Kogi state to compare with already known strains in Nigeria. Vaccination against ND should be stepped up in backyard poultry and instituted in rural poultry for effective control.
\end{abstract}

Keywords: Backyard poultry, Newcastle disease viruses, RT-PCR, Swallow and Swift, Wild birds

Received: 06-08- 2016

Accepted: 01-11-2016

\section{Introduction}

Three Newcastle disease (ND) panzootics were recorded in the past and one of such was caused by feral pigeon fecal contamination of poultry feed materials (Alexander, 2000; Alexander, 2001). Wild birds tend to carry Newcastle disease viruses (NDVs) asymptomatically as reservoirs (Alexander, 2001). Most of the viruses found in wild birds are lentogenic but virulent avian paramyxovirus-1 (APMV-1) has become established in some cormorant (Phalacrocorax spp) populations causing disease in young birds (Seal et al., 1998).

Susceptibility to ND varies widely among poultry and pet birds. Members of the order Phasianiformes particularly chickens are highly susceptible to the disease (Alexander, 2001). Turkeys are less likely to develop severe symptoms and the susceptibility of game birds (pheasants, partridges, quail and guinea fowl) varies with the species (Seal et al., 1998). Ducks and geese usually have inapparent infections but some clinical cases have also been described occasionally in ducks (Alexander, 2001). Outbreaks have been reported in ostriches (order Struthioniformes) while Columbiformes especially pigeons are susceptible to the disease with APMV-1 strains maintained in pigeon populations having some antigenic differences from other APMV-1 isolates, often called pigeon paramyxovirus type 1 (Alexander, 2001). Susceptibility to disease varies widely in Psittaciformes as cockatiels and parrots often die or develop neurological signs but some species tend to carry velogenic strains subclinically (Seal et al., 1998). 
In Africa, ND is a major constraint against the development of both commercial and rural poultry production (Ezeokoli et al., 1984; Sonaiya, 1990; Adene, 1996). In Nigeria, ND is endemic with the occurrence of outbreaks even after vaccination (Sa'idu et al., 2004; Nwanta et al., 2008; Sa'idu et al., 2008). There are little reports of virological evidence of NDVs in wild birds in Nigeria (Echeonwu et al., 1998; Ibu et al., 2009). However, there have been several reports of serological evidence of NDVs in wild birds in other parts of Nigeria which may be responsible for sporadic outbreaks in poultry (Oladele et al., 1996; Sa'idu et al., 2008; Ibu et al., 2009; Ameji et al., 2015).

To the best of our knowledge, there has not been any report of NDVs in poultry and wild birds in Kogi state. This study was designed to determine the prevalence of NDVs in poultry and wild birds in Kogi state, Nigeria.

\section{Materials and Methods \\ Study area}

The study area (Kogi state) lies between Latitude $6^{\circ} 44^{\prime}-7^{\circ} 36^{\prime} \mathrm{N}$ and Longitude $7^{\circ} 49^{\prime}-8^{\circ} 27^{\prime}$ E situated at a height of about $789 \mathrm{~km}$ above sea level and covering a land area of $29,833 \mathrm{Km}^{2}$. The state is bordered by Federal Capital Territory (FCT) and Niger state on the north; Benue and Nasarawa states on the east; Ekiti, Ondo and Kwara states on the west; Edo, Anambra and Enugu states on the south (Wikipedia, 2014).

The vegetation of Kogi state is guinea savannah on the north and a belt of rain forest on the southern fringe with rivers Niger and Benue passing through the state, which later converged at a point to form a confluence. The annual rainfall ranges from 1100 $\mathrm{mm}$ - $1250 \mathrm{~mm}$ starting from April to October (KGSADP, 2009).

The human population of the state is 2,099,046 with the major economic activities of the people being farming, fishing and trading (KGSADP, 2009). The poultry population is estimated to be $3,685,211$ with $91.5 \%$ being rural or backyard poultry and rest being commercial poultry (Adene \& Oguntade, 2006).

\section{Sampling method and sample size}

Multistage, simple random and convenient sampling methods were used for survey locations, poultry and wild birds respectively in the 3 senatorial districts involving 12 LGAs out of the 21 LGAs of Kogi state, Nigeria.

Poultry were sampled from backyard farms, rural households and live bird markets (LBMs) during the survey. The sample size for the study was determined using the formula by Cohen (1988): $\mathrm{N}=$ $\mathrm{Z}^{2} \mathrm{Pq} / \mathrm{L}^{2}$. Sample size for ND survey in poultry from the 3 sampling units $=177 \times 3=531$.
Data on population size of wild bird species and prevalence of ND in wild birds are scanty in Nigeria, a problem adjudged to be a major challenge for designing disease surveys in wild birds in most countries (Wilking et al., 2009). Hence, the sample size was not predetermined but was thought reasonable to limit the sample size to available number of wild birds captured as done by other workers (Teru et al., 2012; Assam, 2014).

\section{Ethical consideration for wild bird survey}

Approval for wild birds' survey was given by the ethical committee, Department of Veterinary Medicine, Ahmadu Bello University, Zaria. One hundred species of wild birds from 8 families were captured alive using mist net and locally made glue traps then, were released into the wild in the field after sampling and being marked on the feet with an indelible marker to avoid resampling. The families of wild birds that were captured and sampled include Accipitridae, Muscicapidae, Apodidae, Hirundinidae, Psittacidae, Ciconidae, Sylvidae and Columbidae.

\section{Cloacal and oropharyngeal swabs sampling}

The oropharyngeal and cloacal swabs were collected after proper restraint of a bird by an assistant with care being taken to avoid harm to the birds and placed in a cryo-vial of viral transport medium containing 10,000 units $/ \mathrm{ml}$ penicillin, $10 \mathrm{mg} / \mathrm{ml}$ streptomycin, $25 \mu \mathrm{g} / \mathrm{ml}$ gentamycin, 5000 units $/ \mathrm{ml}$ mycostatin and $1 \%$ bovine serum albumin in phosphate buffered saline (PBS) (OIE, 2009). The swab samples were maintained at $4^{\circ} \mathrm{C}$ in ice pack upon collection and stored in liquid nitrogen at -70 ${ }^{\circ} \mathrm{C}$ within 4-6 hours until they were processed.

A total of 810 swabs consisting of 710 oropharyngeal and 100 cloacal swab samples were collected from apparently healthy poultry and wild birds respectively during the field survey from June, 2012 to February, 2013 and analyzed for NDVs.

\section{Detection of Newcastle disease viruses}

The swabs were first prepared by spraying the sample tubes with virkon ${ }^{R}$ (Du Pont, USA) to avoid surface contaminants and dried with tissue paper. The samples were then pooled based on location, species and sampling units into sterile tubes. Ten samples were pooled into one in sterile tubes and labeled before the extraction of the nucleic acid (Killian, 2008; Wakawa et al., 2012).

\section{Extraction of nucleic acid}

The ribonucleic acid (RNA) was extracted from each of the pooled test samples using QIAamp Viral RNA mini kit (QIAGEN GmbH, Germany) by spin protocol according to the manufacturer's instructions. The 
QIAamp Mini spin column was discarded and the eluted RNA was stored at $-20^{\circ} \mathrm{C}$ until used.

Preparation of polymerase chain reaction master mix The master mix for the $25 \mu \mathrm{l}$ final volume PCR was prepared from stock of reagents containing nuclease free $\mathrm{H}_{2} \mathrm{O}, 10 x$ PCR Buffer, $50 \mathrm{mM} \mathrm{MgCl} 2,10 \mathrm{mM}$ deoxynucleoside triphosphate (dNTP), $10 \mu \mathrm{M}$ each of oligonucleotide (APMV-1 and $121 \mathrm{bp}$ - forward and reverse primers), $20 \mathrm{U}$ of reverse transcriptase, $5 U$ of ribonuclease inhibitor, $5 \mathrm{U}$ of Ampli -6 Taq DNA polymerase (all reagents by Applied Biosystems, USA) and $5 \mu \mathrm{l}$ of RNA extract. The APMV-1 forward and reverse primers targeting the $M$-gene of $121 \mathrm{bp}$ size with the following sequences: $\mathrm{F}=5^{\prime}$-AGTGATGTGCTCGGGACCTTC- ${ }^{\prime}$ and $\mathrm{R}=5^{\prime}$ CCTGAGGAGAGGCATTTGCTA-3' were used (Wise et al., 2004).

\section{Reverse transcription- polymerase chain reaction}

The conventional one step RT - PCR was used to amplify sample in final reaction mixture of $25 \mu \mathrm{l}$. Thermocycling was done in GeneAmpR PCR System 9700, Applied Biosystems (USA) with the following cycling conditions: activation at $50^{\circ} \mathrm{C}$ for $20 \mathrm{~min}$ and initial denaturation at $95^{\circ} \mathrm{C}$ for $15 \mathrm{~min}$ (stages I \& II once), denaturation at $94^{\circ} \mathrm{C}$ for $45 \mathrm{sec}$, annealing at $60^{\circ} \mathrm{C}$ for $45 \mathrm{sec}$, elongation at $72^{\circ} \mathrm{C}$ for $45 \mathrm{sec}$ (stage III 40 times), final elongation at $72^{\circ} \mathrm{C}$ for $5 \mathrm{~min}$ and hold at $4^{\circ} \mathrm{C}$ until used (stage IV once).

\section{Agarose gel electrophoresis of the amplicons}

A $1.5 \%$ agarose gel was made and placed in the electrophoresis tank, submerged by Tris-Borate Ethylene diamine tetra-acetic Acid (TBE) buffer. The amplicons were mixed with a loading dye (blue/green, Promega ${ }^{\circledR}$ on a parafilm paper in the ratio of 2:8 and loaded in the wells of the gel. One $\mathrm{Kb}$ plus DNA ladder (Fermentas ${ }^{\circledR}$ ) was used as band marker with each lane of the wells having positive and negative controls. The electrophoresis voltage regulator was set at $120 \mathrm{~V}$ for $35 \mathrm{~min}$ after which the bands were read in a Gel Doc $\mathrm{XR}^{+}$with Image LabSoftware (BIO - RAD Molecular Imager ${ }^{\circledR}$, USA) viewed on a computer monitor. The positive samples had the presence of cDNA bands corresponding to the region of $121 \mathrm{bp}$ specific for the genes generated by the pairs of primers used in the amplification of the RNA extract of test samples.

\section{Statistical analysis of survey areas}

The LGAs were grouped into LGAs with captured wild birds and LGAs without wild birds captured as well as into two contiguous zones, A and B for evaluating epidemiological characteristics.

The LGAs where wild birds were captured include; Ankpa, Ajaokuta, Dekina, Lokoja, Ofu and Olamaboro while the LGAs where wild birds were not captured include; Adavi, Kabba/Bunu, ljumu, Mopamuro and Okene respectively. On the other hand, LGAs within contiguous zone $A$ were those in the west and central senatorial districts that include; Adavi, Ajaokuta, ljumu, Kabba/Bunu, Lokoja, Mopamuro, Ogori-Mangogo and Okene while those within contiguous zone $\mathrm{B}$ were those in the eastern senatorial district that include; Ankpa, Dekina, Ofu and Olamaboro respectively. These groups were compared using $\chi^{2}$ and relative risk of infection as odd ratio.

Table 1: Prevalence of Newcastle disease virus in the surveyed sampling units and Local Government Areas of Kogi state, Nigeria $(n=490)$

\begin{tabular}{llllll}
\hline Local Government Area & \multicolumn{4}{c}{ Positive samples to NDVs in different sampling units } \\
\cline { 2 - 5 } & $\begin{array}{l}\text { Backyard farm } \\
(\%)\end{array}$ & $\begin{array}{l}\text { Rural household } \\
(\%)\end{array}$ & $\begin{array}{l}\text { Live bird market } \\
(\%)\end{array}$ & $\begin{array}{l}\text { Wild bird } \\
(\%)\end{array}$ & $\begin{array}{l}\text { Total Positive } \\
(\%)\end{array}$ \\
\hline Ankpa & $10(6.7)$ & $30(23.1)$ & $0(0.0)$ & $10(16.7)$ & $50(71.4)$ \\
Adavi & $10(6.7)$ & $10(7.7)$ & $0(0.0)$ & $0(0.0)$ & $20(50.0)$ \\
Ajaokuta & $10(6.7)$ & $10(7.7)$ & $0(0.0)$ & $0(0.0)$ & $20(50.0)$ \\
Dekina & $10(6.7)$ & $10(7.7)$ & $30(20.0)$ & $10(16.7)$ & $60(100.0)$ \\
ljumu & $40(26.7)$ & $10(7.7)$ & $20(13.3)$ & $0(0.0)$ & $70(77.8)$ \\
Kabba/Bunu & $20(13.3)$ & $0(0.0)$ & $10(6.7)$ & $0(0.0)$ & $30(42.9)$ \\
Lokoja & $0(0.0)$ & $20(15.4)$ & $0(0.0)$ & $0(0.0)$ & $20(22.2)$ \\
Mopamuro & $10(6.7)$ & $10(7.7)$ & $20(13.3)$ & $0(0.0)$ & $40(66.7)$ \\
Ofu & $10(6.7)$ & $10(7.7)$ & $10(6.7)$ & $20(33.3)$ & $50(83.3)$ \\
Ogori-Mangogo & $30(20.0)$ & $0(0.0)$ & $10(6.7)$ & $0(0.0)$ & $40(57.1)$ \\
Okene & $0(0.0)$ & $10(7.7)$ & $30(20.0)$ & $0(0.0)$ & $40(44.4)$ \\
Olamaboro & $0(0.0)$ & $10(7.7)$ & $20(13.3)$ & $20(33.3)$ & $50(71.4)$ \\
Total & $150(57.7)$ & $130(61.9)$ & $150(62.5)$ & $60(60.0)$ & $490(60.5)$ \\
\hline
\end{tabular}




\section{Results}

A total of $490(60.5 \%)$ swabs from poultry and wild birds in the survey areas were positive for NDVs (Figure I and Table 1). On the basis of LGAs, the prevalence of NDVs was $100 \%$ for Dekina LGA; $83.3 \%$ for Ofu LGA; 77.8\% ljumu LGA; 71.4\% each for Ankpa and Olamaboro LGAs; $66.7 \%$ for Mopamuro LGA, 57.1\% for Ogori-Mangogo LGA; 50.0\% each for Adavi and Ajaokuta LGAs; $44.4 \%$ for Okene LGA; $42.9 \%$ for Kabba/Bunu LGA and $22.2 \%$ for Lokoja LGA respectively (Table 1). However, on the basis of sampling units, the prevalence of NDVs was $57.7 \%$

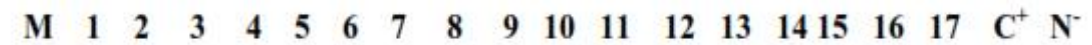

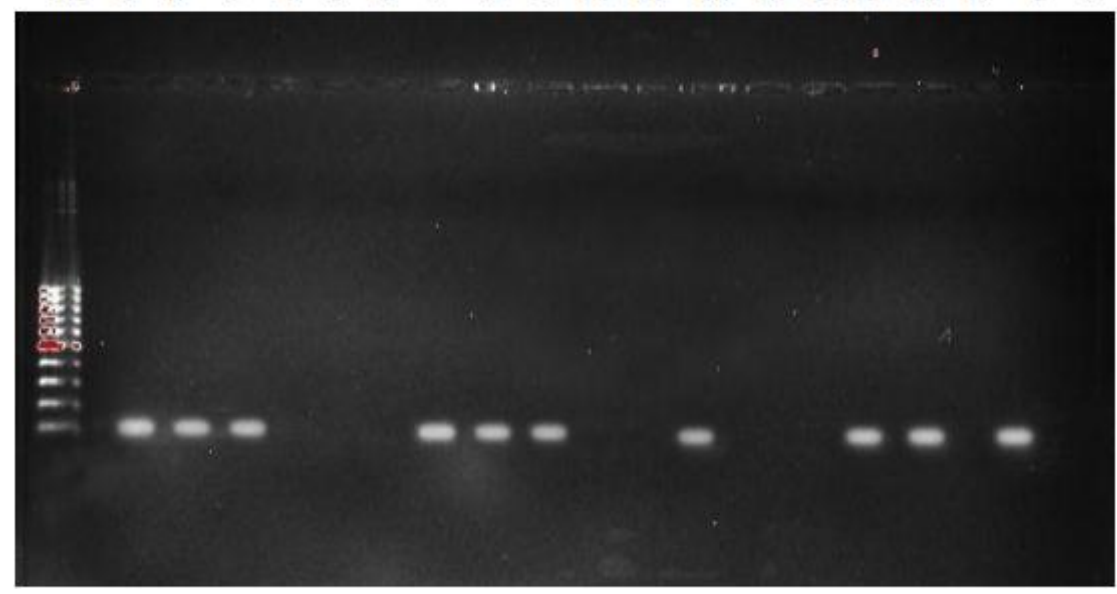

Figure I: Newcastle disease virus RT-PCR results of oropharyngeal and cloacal swabs from poultry and wild birds in the surveyed areas of Kogi state. Pooled samples $1-17$ with $1,2,3,7,8,9,12,15$ and 16 having positive cDNA bands corresponding to $121 \mathrm{bp}$ of the set of primers used in amplification, $\mathbf{M}=$ molecular marker, $\mathbf{C}^{+}=$positive control, $\mathbf{N}^{-}=$negative control for backyard farms, $61.9 \%$ for rural household, $62.5 \%$ for live bird markets and $60.0 \%$ for wild birds respectively (Table 1 ). Similarly, based on avian species, prevalence of NDVs was $59.7 \%$ for chicken, $66.7 \%$ for turkey and duck, $83.3 \%$ for swallow (Hirundo spp), $71.4 \%$ for swifts (Apus spp) and zero for laughing dove (Streptopelia senegalensis) respectively (Table 2 ). The $\chi^{2}$ values of backyard poultry sampling unit against other sampling units (OR $=0.70,95 \% \mathrm{Cl}=0.28-1.76), \mathrm{LGA}$ without wild bird captured against LGA with wild birds captured and poultry species against wild bird species $(\mathrm{OR}=0.98,95 \% \mathrm{Cl}=$ 0.25 - 3.77) were not significant but that of contiguous areas $A$ against contiguous areas $B$ were significant $(\chi 2=6.59, \mathrm{p} \leq 0.01, \mathrm{OR}=$ 4.10 at $95 \% \mathrm{Cl}=1.34-12.28)$ (Table 3).

\section{Discussion}

The overall prevalence of NDVs of $60.5 \%$ seen in this study was an indication of the high viral activity in the study area. The birds sampled were apparently healthy which showed that ND virus strains in circulation were either vaccine strains or lentogenic field strains with concomitant mild

Table 2: Prevalence of Newcastle disease virus among the avian species surveyed in Kogi state, Nigeria $(n=490)$

\begin{tabular}{lll}
\hline Avian species & No. tested & No. positive for NDVs (\%) \\
\hline Chicken & 620 & $370(59.7)$ \\
Turkey & 60 & $40(66.7)$ \\
Duck & 30 & $20(66.7)$ \\
Swallow & 60 & $50(83.3)$ \\
Swift & 14 & $10(71.4)$ \\
Dove & 26 & $0(0.0)$ \\
Total & 810 & $490(60.5)$ \\
\hline
\end{tabular}

Table 3: The relative risk of Newcastle disease virus infection in different categories of birds in the surveyed areas of Kogi state

\begin{tabular}{|c|c|c|c|c|}
\hline \multirow[t]{2}{*}{ Category of odds } & \multirow[t]{2}{*}{ OR value } & \multicolumn{2}{|c|}{$95 \% \mathrm{Cl}$} & \multirow[t]{2}{*}{ Chi-square } \\
\hline & & Lower & Upper & \\
\hline Backyard poultry/other poultry \& wild bird & 0.698 & 0.277 & 1.758 & $\chi^{2}=0.583, p \leq 0.445$ \\
\hline $\begin{array}{l}\text { Areas without captured wild bird/Areas with captured wild } \\
\text { bird }\end{array}$ & 0.992 & 0.401 & 2.457 & $\chi^{2}=0.001, p \leq 0.986$ \\
\hline Poultry species/wild bird species & 0.977 & 0.253 & 3.774 & $\chi^{2}=0.021, p \leq 0.973$ \\
\hline Contiguous zone $\mathrm{A}$ /contiguous zone $\mathrm{B}$ & 4.050 & 1.336 & 12.281 & $\chi^{2}=6.587, p \leq 0.01^{*}$ \\
\hline
\end{tabular}


disease and production losses. However, there is a revelation that the highly virulent strains could evolve from virus strains of low virulence by mutation which may signal danger if there is cocirculation of strains of APMV-1 in wild birds and poultry (Alexander, 1997).

The prevalence of NDVs in wild birds found in this study is much higher than the prevalence of $7.0 \%$ determined in a previous study in north central Nigeria (Ibu et al., 2009). The wide gap in the prevalence may be due to the larger sample size and wide area of coverage in the former study compared to the present study that involved some LGAs within a state. In addition, the former study used virus isolation to determine the prevalence, a method of high specificity but very low sensitivity compared to RT-PCR used in the present study.

The low prevalence of NDVs in backyard poultry farms might be an indication of low vaccine take in recent vaccinations with live ND vaccines which further meant that chickens in this cluster would not be properly protected against ND in the event of an outbreak in the study area, it could also be that sampled poultry were being challenged by ND field virus or late stage of ND vaccination which had seroconverted. Poultry from LBMs had the highest prevalence of NDVs probably due to the pool of vaccinated poultry from backyard and naïve susceptible rural poultry in the LBMs. The implication of this finding is that there is circulation of NDVs in the LBMs with the likely outbreak of ND when naïve birds are introduced and may results in disease spread to households and farms. Ameji (2010) reported that most rural and backyard poultry farmers sourced rearing birds from the LBMs in the study area.

The prevalence of NDVs in rural poultry where routine vaccination is not done is also high. Rural poultry are mostly kept on free range where they roam to scavenge for food and in the process may pick ND virus from the environment in refuse dumps, contaminated food and water by infected, vaccinated poultry flocks and wild birds or even via aerosol. Seropositivity to ND antibodies had been detected in unvaccinated flocks in Australia, Switzerland and elsewhere where poultry are kept on free range with direct contact with wild birds and ducks which often do not show clinical disease but do shed ND virus (Schelling et al., 1999).

Chickens had the lowest prevalence of NDVs among the species of poultry sampled. This might be due to the vaccination of chickens in backyard farms with ND virus vaccines with seroconversion which make them less susceptible to NDVs. However, chickens sampled include those from LBM and rural poultry and not entirely from backyard poultry farms where routine vaccination is done hence, it is reasonable to say that the circulating NDVs may not entirely be from vaccinal strains.

All the Swallow (Hirundo spp) and Swift (Apus spp) tested were positive to the NDVs contrary to an earlier study carried out within three states of north central Nigeria that failed to detect the virus in these species of wild birds (Ibu et al., 2009). In the earlier study, attempt was made to isolate NDVs from cloacal swabs which failed to yield any positive result. It has been shown to be often difficult isolating ND virus from seropositive flocks (Schelling et al., 1999). The prevalence of NDVs in Hirundo and Apus spp were indications of the susceptibility of these species of wild birds to infection with the virus. Hirundo spp and Apus spp roost or breed in old buildings, barns and around poultry houses and might have been infected via aerosol or contamination of feed and water by vaccinated poultry flock and vice versa. The absence of NDVs in Laughing dove (Streptopelia spp) was in agreement with the work of lbu et al. (2009) which failed to detect ND virus in this species.

Prevalence of ND virus was found in duck. Ducks do not show clinical disease but are known carriers of the avirulent NDVs which may mutate to virulent ND virus strains (Alexander, 1997; Alexander, 2001). The risk of NDVs transmission from ducks or water birds may be either through direct or indirect contact with poultry flocks such as contaminated feed and water or infection of wild bird species at common water sites and then transmission of the infection into poultry flocks.

The prevalence of NDVs in turkey indicated the susceptibility of this species to the virus. This finding has an implication that rearing of turkeys and chickens together will result in ND outbreak with devastating effect on chicken production as clinical disease in turkeys is often variable.

Dekina LGA had the highest NDVs prevalence probably due to the age and type of poultry sampled from this LGA. The poultry sampled in Dekina LGA were broilers from backyard poultry farms and rural poultry from LBMs than in any of the LGAs. This is closely followed by ljumu LGA then, Ofu, Ankpa and Olamaboro LGAs. These four LGAs apart from ljumu are contiguous (contiguous zone B) to one another on the eastern flank of Kogi state and the findings might be linked with poultry husbandry practices in the areas. All the birds sampled were apparently healthy hence, the high prevalence of NDVs indicated the infection of birds with wild lentogenic or vaccinal strains of ND virus. Ankpa, Dekina, Ofu and Olamaboro LGAs may be at risk of an outbreak of ND in backyard poultry farms and the high prevalence of NDVs in these LGAs might be due to the important role of wild birds in the maintenance and dissemination of NDVs within this contiguous 
zone. Wild birds were surveyed in all the LGAs in this zone with almost all the cloacal swabs being positive to NDVs.

The detection of relatively low prevalence of NDVs in ljumu, Mopamuro, Ogori-Mangogo, Okene, Kabba/Bunu and Lokoja LGAs might be due to sampling of older birds from vaccinated flocks which had antibodies that made them less susceptible to infection with the NDVs. These LGAs were grouped as contiguous zone $A$ on the west and central flanks of Kogi state. It was also clear that wild birds played little role in the dissemination of NDVs in these areas as wild birds surveyed in this contiguous zone had none of the cloacal swabs being positive for NDVs. The odds of infection with NDVs in the contiguous zone A were 4 times higher than that of contiguous zone $B$. This was due to the fact that more of the tested swabs with $52 \%$ being positive for NDVs were from zone A. The implication of the finding is that contiguous zone A had more backyard poultry farms and LBMs as well as other factors which favor the infection of birds with NDVs. The odds of infection in

\section{References}

Adene DF (1996). International poultry health problems: Perspective from the poultry industry in Africa. In: Proceedings, twentieth World Poultry Congress (1-5 September 1996), New Delhi, India, Vol. 2, Pp 401-414.

Adene DF \& Oguntade AE (2006). The structure and importance of the commercial and rural based poultry industry in Nigeria. FAO study (October, 2006), Rome, Italy. Pp 1-70.

Alexander DJ (1997). Newcastle disease and other avian paramyxoviridae infections. In: Diseases of Poultry, Calnek, BW, Barnes HJ, Beard CW, McDougnald IR \& Saif YM, edotors), tenth edition. lowa state University Press, Ames, lowa, United states of America, Pp: 541-547.

Alexander DJ (2000). Newcastle disease and other avian Paramyxoviruses. In: Revue Scientifique et Technique de l'OIE. Pp 443-446.

Alexander DJ (2001). The Gordon Memorial Lecture: Newcastle disease. British Poultry Science, 42(1): 5-22.

Ameji NO (2010). Antibodies to avian influenza, Newcastle disease, Gumboro disease in chickens and awareness on avian influenza in Kogi state, Nigeria. MSc Thesis, Department of Veterinary Medicine, Ahmadu Bello University, Zaria-Nigeria. Pp 87-122.

Ameji NO, Sa'idu L \& Abdu PA (2015). Newcastle disease antibodies in apparently healthy wildbirds in Kogi state, Nigeria. Research Journal of Veterinary Sciences, 8(3): 52-60.

Assam A (2014). Some wild bird infections, trade and sellers' knowledge, attitude and practices on backyard poultry was less than that of other poultry and wild bird species probably due to the vaccination of backyard poultry against ND infection. Moreover, the odd of infection in LGAs without wild birds surveyed was less than that from LGAs where wild birds were surveyed. The high odd of infection in areas with wild birds surveyed under scored the role of wild birds in the epidemiology of ND.

The study showed the presence of NDVs in poultry and wild birds in the study area, a pointer of the endemicity of NDV in Kogi state. The limitations of the effect of small sample size for wild birds on the results of the study did not permit the making of valid conclusions as to the extent of prevalence of NDVs in wild birds and species affected. However, the presence of the NDVs in a single species is a proof of the likely role free flying wild birds may play in the epidemiology of the disease. It is recommended that vaccination of backyard poultry against ND should be stepped up as well as being adopted in rural poultry. Also, poultry should be screened from having contact with wild birds.

biosecurity in Kaduna state, Nigeria. $P h D$ Thesis, Department of Veterinary Medicine, Ahmadu Bello University, Zaria. Pp 72-100.

Cohen J (1988). Statistical power analysis for the behavioral sciences, second edition. Lawrence Erlbaum Associates, Publishers, Hillsdale, New Jersey. Pp 127-250.

Echeonwu GO, Ireogbu Cl \& Emeruwa AC (1998). Recovery of velogenic Newcastle disease virus from dead and healthy free roaming birds in Nigeria. Avian Pathology, 22(2): 383-387.

Ezeokoli CD, Umoh JU, Adesiyun AA \& Abdu PA (1984). Prevalence of Newcastle disease virus antibodies in local and exotic chickens under different management systems in Nigeria. Bulletin of Animal Health and Production in Africa, 32(2): 253- 257.

Ibu OJ, Okoye JOA, Adulugba EP, Chah KF, Shoyinka SVO, Salihu E, Chukwuedo AA \& Baba SS (2009). Prevalence of Newcastle disease viruses in wild and captive birds in central Nigeria. International Journal of Poultry Science, 8(6): 574-578.

Killian LM (2008). Avian influenza virus sample types, collection, and handling. In: Spackman, E. (Ed.). Methods in Molecular Biology, Vol. 436. Humana Press, Totowa, New Jersey, Pp 120167.

Kogi state Agricultural Development Projects (KGSADP) (2009). In: Encyclopaedia Britannica. http://www.britannica.com/kogistate/agric/i ndex.html, retrieved 10-11- 2009. 
Nwanta JA, Abdu PA \& Ezema WS (2008). Epidemiology, challenges and prospects for control of Newcastle disease in rural poultry in Nigeria. World's Poultry Science Journal, 64(1): $119-127$.

Office of the international epizootics (OIE) (2009). Avian influenza. OIE Terrestrial Manual 2009, sixteenth edition, www.oie.int/manual.html, retrieved 04-04-2012.

Oladele SB, Kazeem HM \& Raji MA (1996). Survey for antibodies to infectious bursal disease, Newcastle disease and fowl pox in ducks, pigeons and guinea fowls in Zaria. Nigerian Veterinary Journal (special edition), 1: 85-87.

Sa'idu L, Tekdek LB \& Abdu PA (2004). Prevalence of Newcastle disease antibodies in domestic and semi-domestic birds in Zaria, Nigeria. Veterinarski Arhiv, 74(4): 309-317.

Sa'idu, L., L.B. Tekdek, P.A. Abdu, J.A. Umoh, \& J. Adamu (2008). Comparison of the safety, immunogenicity and potency of La Sota and V4 Newcastle disease vaccines. Sahel Journal of Veterinary Sciences, 7(1): 8-15.

Schelling E, Thur B, Griot C \& Audige L (1999). Epidemiological study of Newcastle disease in backyard poultry and wild bird populations in Switzerland. Avian Pathology, 28(3): 263-272.

Seal BS, King DJ, Locke DP, Senne DA \& Jackwood MW (1998). Phylogenetic relationships among highly virulent Newcastle disease virus isolates obtained from exotic birds and poultry from 1989 to 1996. Journal of Clinical Microbiology, 36(4):1141-1145.

Sonaiya EB (1990). The context and prospects for development of smallholder rural poultry production in Africa. In: Proceedings, CTA Seminar on Smallholder Rural Poultry Production (9-13 October 1990), Thessaloniki, Greece, Vol. 1, Pp 35-52.

Teru CV, Manu SA, Ahmed GI, Junaidu K, Newman S, Nyager J, Iwar VN, Mshelbwala GM, Joannis T, Maina JA \& Apeverga PT (2012). Situationbased survey of avian influenza viruses in possible Bridge species of wild and domestic birds in Nigeria. Influenza Research and Treatment, doi:10.1155/2012/567601.

Wakawa AM, Abdu PA, Oladele SB, Sa'idu L \& Owoade AA (2012). Surveillance for Avian Influenza H5 Antibodies and Viruses in Commercial Chicken Farms in Kano state, Nigeria. International Journal of Animal and Veterinary Advances, 4(5): 321-325.

Wikipedia (2014). States of Nigeria. http://en.wikipedia.org/w/Kogi, retrieved 1411-2014.

Wilking H, Ziller M, Staubach C, Globig A, Harder TC \& Conraths FJ (2009). Chances and limitations of wild bird monitoring for the avian influenza virus H5N1: detection of pathogenshighly mobile in time and space. PLOS ONE, 4(8). ID e6639.

Wise MG, Suarez DL, Seal BS, Pedersen JC, Senne DA, King DJ, Kapczynski DR \& Spackman E (2004). Development of a real-time reversetranscription PCR for detection of Newcastle disease virus RNA in clinical samples. Journal of clinical Microbiology, 42(1): 329-338. 